\title{
THE NECESSITY OF TERRORISM INCLUSION IN THE CATEGORY OF INTERNATIONAL CRIMES STRICTO SENSU
}

\author{
G. Paraschiv
}

\section{Gavril Paraschiv}

Faculty of Law and Public Administration, Craiova,

"Spiru Haret" University, Romania

*Correspondence: Gavril Paraschiv, Râmnicu Vâlcea, 30 General Magheru St., Vâlcea, Romania

E-mail: gavril.paraschiv@yahoo.com

\section{Abstract}

Terrorism is a process of inducing fear on the population, by means of repeated violent actions, used by the individuals, groups or state actors, for criminal motives or political claims, whose aims, unlike assassinations, do not represent the main targets. The unmediated victims of violence, are generally chosen randomly or selectively (representative or symbolic targets), from a certain population. Terrorist acts generate messages and the threat and violence, as a communication process between the terrorist (organization), immediate victims and main targets, are used in order to terrify and manipulate the population, which is transformed in a target of terror, a target of demands or a target of attention, depending on the target pursued: intimidation, coercion or propaganda

Keywords: terrorism, international cooperation, reglementation, repression, international criminal law

\section{Introduction}

International criminal law- formed of internal legal norms, some adopted in conformity with international conventions - defends the internal order of every state, but also contributes to the defense of international legal order, the acts that combine to form its structure also having an element of extraneity, which may refer to: place of committing the acts or of producing their consequences, the nationality of the perpetrators, the place where they are after committing the offenses etc.

Unlike the above-mentioned, the international criminal law represents the set of regulations, recognized in international relations, which target the defense of international legal or social order by repressing the violations brought to precepts of public international law ${ }^{l}$.

\section{Terrorism - international crime stricto sensu?}

Being the distinct branch of public international law, the international criminal law is called upon to protect, by sanctioning the persons guilty of having committed serious offenses, the peace and security of the entire humanity, the development of relations between states in accordance with the norms of law and morality, the existence and perenity of certain fundamental values of humanity ${ }^{2}$.

In the framework of preoccupations of a legal nature of the different international forums we may also include the elaboration of studies and international convention projects

\footnotetext{
${ }^{1}$ Glaser St., Droit international pénal conventionnel, tome ${ }^{\mathrm{er}}$, Etablissements Emile Bruylant, Brusells, 1970, p. 16-17.

2 Paraschiv D. Şt., „Considerații privind dreptul internațional penal”, in „Dreptul românesc în contextul european - Aspecte teoretice şi practice”, Sitech Publishing, Craiova, 2008, p. 100-105.
} 
for widely modifying the institutions of criminal law belonging to states concerning the regulations which target the sanctioning of grave infractions, as well as codifying and standardizing certain regulations regarding basic institutions which are included in the general part of criminal law: tendency, the forms of penal participation, legitimate defense, necessity state, relapse, safety measures, extradition, legal effects of foreign decisions etc., with the intention of elaborating an universal penal code ${ }^{3}$. These preoccupations target, among others, to unify internal penal legislations in issues related to the general interest of humanity, expressed in the international regulations, means to aim at sanctioning those who commit offenses which lead to the achievement of universal values.

In addition to the international crimes stricto sensu ${ }^{4}$, which are under the international legal jurisdiction, states have established by means of international conventions that other acts also represent a social danger, such as: terrorism, placing or illegal use of weaponry, racial discrimination, apartheid, slavery, torture, illegal experiments on human subjects, producing serious and intentional damage upon the environment (caused in other circumstances than those specific to crimes against humanity, war crimes or genocide), piracy, traffic and production of drugs, traffic of obscene publications, theft of nuclear material, illegal use of mail, interference with submarine cables, forgery and counterfeiting of currency, corrupting official foreign persons etc.

From the above-mentioned crimes, the Rome Statute ${ }^{5}$ regulates: racial discrimination, apartheid, slavery, torture, illegal experiments on human subjects, producing serious and intentional damage upon the environment, as acts which are comprised in the international crimes stricto sensu, related to the competence of the International Penal Court, when they are committed in the context of certain circumstances, specific to international crimes stricto sensu, such as: for war crimes, their committance in the framework of an armed conflict; for crimes against humanity, committing them as part of a systematic attack or expanded against the civil population etc.

In the absence of special circumstances of aggravation, specific to international crimes of the competence of the International Penal Court, the international illicit acts enumerated above no longer represent international crimes stricto sensu, being considered of a reduced level of peril, thus they have remained in the exclusive competence of the national courts. Regulating the mentioned infractions at an international level consists of establishing an obligation to incriminate these acts by the state parties at the international conventions concluded in this purpose, as well as a general obligation of interstatal cooperation in view of research, arrest, judging and condemning those who commit illicit acts in international conventions ${ }^{6}$.

The level of social peril of some of the illicit acts regulated internationally is still very high, the international conventions which regulate them presenting characteristics of customary law, with norms of jus cogens, which would justify framing them in the category

\footnotetext{
${ }^{3}$ Crețu V., 1996, Drept internațional penal, Societatea “Tempus” Publishing, Romania, Bucharest, p. 11.

${ }^{4}$ These are: crimes against humanity, war crimes, genocide, and crime of aggression.

${ }^{5}$ Adopted on the 17th of July 1998, in the framework of the Diplomatic Conference at Rome of the Plenipotentiaries of the United Nations.

${ }^{6}$ The international convention regarding the repression of the expansion of obscene traffic publications, adopted in 1923 under the aegida of the Society of Nations; the unique convention concerning narcotics, signed in New York in 1961; Convention concerning psychotropic substances, concluded in Viena in the 21st of February 1971; Convention from Montego Bay (Jamaica) for acts which infringe the sea law, from the 10th of December 1982; Convention concerning illicit narcotics and psychotropic substances traffic, concluded in Viena on the 20th of December 1988; Convention referring to slavery from 1926, completed in 1956 by the additional convention concerning the abolishing of slavery, of slave traffic and institutions and practices related to slavery; Convention for repressing and abolishing the traffic of human beings and exploiting prostitution, concluded on the 2 nd of December 1949; Convention concerning the elimination of all forms of discrimination against women, concluded on the 18th of December 1979; Convention concerning children's rights from 1989.
} 
of international crimes stricto sensu and rethinking the means of preventing, following and punishing those acts.

This type of international illicit act would be international terrorism, which is used as a method of achieving one's civil and political purposes by the undiscerning use of violence. Terrorist actions occurred along history ${ }^{7}$, as a primary method of combat practiced by extremist groups as to achieve the satisfaction of certain demands by the governments of some states or as a way of revenge for certain measures which were taken.

Terrorist acts consist of attacks on state presidents or other persons who occupy high positions in the state, destruction acts of important state or private property, bombing attacks against the civil population, assaulting the diplomatic missions, attempts against personalities of the public life, attacking crowded means of transport, public institutions or commercial companies etc.

The reaction of the international community takes shape in adopting conventions, which incriminate and sanction terrorist acts at international levels, or in establishing methods and mechanisms to prevent and minimize the effects of terrorist attacks.

Thus, among the first reactions of the international community in this sense, we mention the convocation of a conference regarding the international repression of terrorism, which followed the assassination of king Alexander I of Yugoslavia and the Minister of Foreign Affairs of France in the year 1934, as a result of the terrorist attack in Marseille. In the framework of this conference the text of the International convention for preventing and suppressing terrorism was elaborated, signed Geneva in the year 1937, by which the participating states undertook to punish the persons guilty of committing terrorist acts.

After the Second World War, the terrorism acts committed in various forms of manifestation were in the attention of the international community, which adopted several conventions means to repress these acts ${ }^{8}$.

The conventions which regulate the different acts of terrorism no not embody a complete and complex definition of this illicit international act, which gains as time passes new dimensions, however they segmentally describe the international acts of terrorism.

The issue referring to the notion of terrorism was firstly disputed internationally in the framework of the process of unifying principles of penal responsibility at the beginning of the 20th century, the Conference in Varsovia for unifying penal law (1927), unsuccessfully trying to define this phenomenon. The final resolution of the conference suggested not only sanctioning terrorism acts, but also other acts such as: piracy, money forgery, slave commerce, as well as the international use of means capable of creating a common peril.

At the second conference on this subject, taking place in Bruxelles in the year 1930, the following definition of terrorism was formulated: „, The deliberate use of means capable to produce a common peril, represents acts of terrorism which consist of crimes against life and physical integrity of certain persons, or which are pointed against private or statal property, in the purpose of achieving political or social objectives", and a year later, at the Conference of Paris, a new definition was formulated: „Anyone, in the purpose of terrorizing the population, uses against persons and properties bombs, mines, inflammable devices, explosives, firearms

\footnotetext{
${ }^{7}$ Over 2500 years ago, the military genius Sun Tzu, author of "The Art of War"" showed which the essence of terrorism is "kill one, terrify ten thousand".

${ }^{8}$ Convention in Tokyo from 1963 regarding the offenses and certain acts committed on the board of the aeroplane, the Haga Convention from 1970 for repression of the illicit capture of aeroplanes; Convention in Montreal from 1971 for supressing illicit acts against civil aviation security; European convention from 1976 for supressing terrorism; Convention from 1973 concerning the prevention and repression of offenses pointed against persons who enjoy international protection, including diplomatic agents; International convention from 1979 concerning the taking of hostages; Convention in Montreal from 1991 regarding the markage of plastic explosives as for detecting; International convention for repression terrorist attacks using bombs (New York, 1997); Convention regarding the repression of terrorism financing (New York, 1999).
} 
or other means, or anyone who interrupts or attempts to interrupt a public service or of public utility will be sanctioned", however none of these definitions was ever adopted ${ }^{9}$.

Defining terrorism was also a challenge for the UNO, the member states having attempted for 30 years to establish an universal definition of terrorist acts, however their efforts were hampered by the differences in opinions generated by political interests, which would explain the great number and diversity of the conventions adopted for fighting concrete facts, considered as being terrorist acts ${ }^{10}$. Although, in a common declaration, made on the 9 th of December 1994, is affirmed that "intentional or calculated criminal acts that provoke an atmosphere of terror in the public opinion, of a group of persons of individuals, for political purposes, are not justifiable in any circumstance, given any considerations of a political, philosophical, ideological, racial, ethnical, religious or another, which may be invoked for justifying them" $" 1$.

Recent attempts to reach an international agreement regarding a comprehensive definition of international terrorism occurred during the negotiations for the Statute of International Criminal Law, when the proposal to include terrorism in the framework of ratio materiae Court jurisdiction was made. However, these efforts proved to be unsuccessful. By limiting the competence of the International Penal Court in the four categories of customary international crimes (aggression crimes, war crimes, genocide and crimes against humanity), the political will of the international community manifested in the sense of not including terrorism on the list of international crimes stricto sensu, as the delegations of the Arab States which refused, argumented that the future Court will be politicized if terrorism were included in the category of international crimes stricto sensu.

In the last decades, terrorist attacks appealed to more destructive methods, targeting quantitative aspects, such as killing a large number of persons or huge material destruction ${ }^{12}$. Contemporary terrorism has also varied its financing resources, forming international affiliations based on religious or ideological affinities, as well as common hate against the great nations.

The unparalleled international organization of terrorist groups ${ }^{13}$ permits attacks with a level of high peril, which is hardly detectable or preventable, which would impose new methods of incriminating and legal sanctioning of these acts.

Although the majority of the world's states express frim positions against terrorism, there are countries which are suspected of supporting terrorism, or event using it of their own free will, as an element of state policy ${ }^{14}$.

The existent international conventions do not ensure a sufficient reaction for eradicating this phenomenon whose manifestations are becoming more and more numerous and difficult to counter-attack, and international obligations stipulated by these conventions for the state parties -of incriminating and internal sanctioning of different acts of terrorism

\footnotetext{
${ }^{9}$ Năstase A., Aurescu B. \& Jura C., Drept internațional public. Sinteze pentru examen, III-rd edition revised and completed, All Beck Publishing, Bucharest, 2002, p. 342.

${ }^{10}$ Jura C., Terorismul internațional, All Beck Publishing, Bucharest, 2004, p. 20 and fol.

${ }^{11}$ United Nations organization, General Assembly, Declaration concerning measures for eliminating terrorism A/RES/49/60, $9^{\text {th }}$ of December 1994.

${ }^{12}$ For example, the simultaneous terrorist attack in the USA, from the 11th September 2001, resulted in the destruction of the two twin towers in New York and the damaging of the building of Pentagon in $\mathrm{n}$ Washington, as well as the death of over 7000 persons, and in the terrorist attack in Madrid, from the 11th of March 2004, also died a few hundreds of people.

${ }^{13}$ Until recent time, over 20 terrorist groups were identified, from which the most acknowledged from the point of view of terrorist events in which the Arabic terrorist organizations were involved: Hamas, Hezbollah, AlQaida.

${ }^{14}$ In this sense manifest or have manifested the regions of Syria, Sudan and Afghanistan, which ensured funds, refuges, training bases and terrorist weapons. In similar situations were Libia, North Coreea or Cuba. See OnicaJarka Beatrice, Jurisdicția internațională penală, C.H. Beck Publishing, Bucharest, 2006, p. 101.
} 
and of extension of international cooperation activities, such as extraditions of persons accused of committing terrorist acts - do not have the expected efficience, due to the relativity principle of international conventions effects, which can not be mandatory for all states ${ }^{15}$.

Following the terrorist attacks from the 11th of September 2001, Security Council of the United Nations Organization took attitude and adopted, based on the 7th Chapter from the Charter of the United Nations Organization, two resolutions: 1368(2001) from the 12th of September 2001 and 1373(2001) from the 28th of September 2001, in which they classify terrorism as an act of threatening the peace and security of the international security, establishing a series of obligations of fighting and preventing terrorism acts for all states, from which the most important target the obligation of retaining from assuring any form of passive or active support of entities and persons involved in terrorist acts, such as incriminating all terrorist acts and adheration to international conventions which regulate terrorism.

\section{Conclusions}

International terrorism has obtained an unexpected high grade of peril on an international level, thus its legal framing in the categories of international crimes stricto sensu would be imposed, and which are in the competence of the International Penal Court.

The unifying of regulations concerning international terrorism acts and their classification in the conventional plan, in the category of the international crimes stricto sensu would ensure the intervention of international penal jurisdiction and upon the citizens of certain states which have not approved this jurisdiction, for the acts committed on the territory of state parties to this jurisdiction, thus creating a possibility to benefit from the support of the Security Council of the United Nations Organization for bringing the persons accused of international terrorism to international justice. This would be made in order to use even more military measures against states which refuse to submit to the request of handing over to the International Penal Court of the persons pursued, according to the regulations stipulated in the 7th Chapter of the Charter of the United Nations Organization.

\section{Bibliography}

Paraschiv D. Şt., “Considerații privind dreptul internaţional penal”, in „,Dreptul românesc în contextul european - Aspecte teoretice şi practice”, Sitech Publishing, Craiova, 2008;

Onica-Jarka Beatrice, Jurisdicția internațională penală, C.H. Beck Publishing, Bucharest, 2006;

Jura C., Terorismul internațional, All Beck Publishing, Bucharest, 2004;

Năstase A., Aurescu B. \& Jura C., Drept internațional public. Sinteze pentru examen, III-rd edition revised and completed, All Beck Publishing, Bucharest, 2002;

Crețu V., Drept internațional penal, Societatea „Tempus” Publishing, Romania, Bucharest, 1996;

Glaser St., Droit international pénal conventionnel, tome $\mathrm{I}^{\mathrm{er}}$, Etablissements Emile Bruylant, Brusells, 1970.

\footnotetext{
${ }^{15}$ The Afghanistan case that sheltered Ossama Bin Laden, one of the leaders of the terrorist organization AlQaida, suspected of being involved in the terrorist acts from the USA on the 11th of September 2001, is relevant for signalling that international terrorism can not be stopped by customary means regulated on a national or international level.
} 